\title{
Koalisyon Hükümetlerinde Basın Özgürlüğü: Doğru Yol Partisi ve Sosyal Demokrat Halkçı Parti/Cumhuriyet Halk Partisi Örneği $(1991-1996)^{*}$
}

\author{
Freedom of The Press in Coalition Governments: True Path Party and Social Democratic \\ People's Party/Republican People's Party Case (1991-1996)
}

\section{Göksel BASMACI $^{* *}$}

Öz

1991-1996 yılları arasındaki DYP-SHP/CHP koalisyon hükümeti, Türkiye’nin en uzun süre yönetimde kalan koalisyonu olmuştur. Bu süreçte, hükümeti oluşturan partilerde ve liderlerde çeşitli değişiklikler yaşansa da birlikteliğin sürdürüldüğü görülmüştür. Farklı ideolojilerdeki partilerin anlaşması sonucunda kurulan ortaklık döneminde, ekonomi ve hukuk başta olmak üzere, birçok alanda köklü dönüşümler yaşanmıştır. Öte yandan ülke genelinde, terör olayları artmış ve birçok kişi öldürülmüştür. Söz konusu gelişmelerin yanı sıra bu hükümet döneminde, basın alanında da önemli değişikliklerin ve sorunların yaşandığı görülmüştür. Bu doğrultuda, çalışma kapsamında, DYP-SHP/CHP koalisyon hükümeti yönetiminde, basına dair yapılan yasal düzenlemeler ve basının genel durumu incelenmiştir. DYP-SHP/CHP koalisyon hükümetinde, basının özgür olup olmadığını saptamak çalışmanın sorunsalı olarak belirlenmiştir. Bu bağlamda, basın özgürlüğünün ve çıkarılan yasaların ne yönde şekillendiğini ortaya koymak ise çalışmanın amacını oluşturmaktadır. Çalışma, DYP-SHP/CHP koalisyonu dönemindeki basının durumunu yansıtması nedeniyle önem taşımaktadır. Bu doğrultuda yürütülen çalışmada, betimleme yöntemi kullanılmış ve alana ilişkin yazılı kaynaklardan yararlanılmıştır. Sonuç olarak, DYP-SHP/CHP koalisyon hükümeti döneminde basına yönelik yoğun baskı ve denetim uygulandığı saptanmış ve basın özgürlüğünün açık bir şekilde kısıtlandığı görülmüştür.

Anahtar Kelimeler: Basın Özgürlüğü, Demokrasi, Basın Kanunları, Koalisyon, DYP-SHP/CHP Hükümeti

* Bu makale, Marmara Üniversitesi Sosyal Bilimler Enstitüsü Gazetecilik Anabilim Dalında hazırlanan doktora tezinden üretilmiștir.

* Arş. Gör., İstanbul Arel Üniversitesi, İletişim Fakültesi, Gazetecilik, İstanbul, Türkiye, Orcid ID: 0000-0002-4640-9819

Başvuru Tarihi: 12.02 .2019

Kabul Tarihi: $\quad 09.04 .2019$ 


\begin{abstract}
The DYP-SHP/CHP coalition government between 1991 and 1996 became the longest-running coalition in Turkey. In this process, it was observed that although there were changes in the parties and the leaders that formed the government, the unity continued. During the partnership period established as a result of the agreement of parties in different ideologies, radical transformations were experienced in many areas, especially in economics and law. On the other hand, throughout the country, terrorist incidents have increased and many people were killed. In addition to these developments, significant changes and problems were experienced in the press during this period. In this context, legal arrangements made to the press and the general situation of the press were examined under the direction of the DYP-SHP/CHP coalition government within the scope of this study. This study discusses whether the press is free in the DYP-SHP/CHP coalition government. In this context, the aim of the study is to show how the freedom of the press and the laws enacted are shaped. This study is crucial since it reflects the state of the press during the DYP-SHP/CHP coalition period. In this study, the descriptive method and written sources related to the area were used. As a result of this study, it can be stated that during the period of the DYP-SHP/CHP coalition government, intense pressure and control imposed on the press were determined and freedom of the press was clearly restricted.
\end{abstract}

Keywords: Freedom of the Press, Democracy, Press Laws, Coalition, DYP-SHP/CHP Government

\title{
Giriş
}

Demokrasinin en temel şartlarından biri olan basın özgürlüğü, basının var olduğu günden bu yana en tartışmalı kavramlar arasında yer almıştır. Buna istinaden, kişinin öz değeri olan düşünce ve ifade hürriyeti üzerine yükselen basın özgürlügünü sağlamak için birçok kanun geliştirilmiştir. Demokrasinin tam anlamıyla işlediği ve özgürlüğün esas alındığı yönetimlerde basına dair kararlar, çoğulcu ve hürriyet temelli işlerken, demokrasi kültürünün hâkim olmadığı yerlerde ise baskıcı bir yaklaşım sergilenmiştir.

Bu noktada, basın özgürlüğünün belirlenmesinde, ülke yönetiminde söz sahibi olan partilerin demokrasiye olan inancı kadar, yönettikleri sistemin de etkili olduğuna dikkat çekmekte fayda bulunmaktadır. Öyle ki bir ülkeyi yöneten iktidarın, tek partili ya da çok partili sistem içinde olması, politikaların şekillenmesinde belirleyici bir unsur olarak öne çıkmaktadır. Çok partili sistemde tercih edilen bir hükümet şekli olan koalisyon yönetimi, demokratik yapısı nedeniyle, basın açısından ideal bir sistem olarak değerlendirilebilir. Eşitlik, özgürlük ve uzlaşı kültürünün olduğu bu sistemlerde, basının demokratik bir zemin üzerinde hareket etmesi beklenmektedir.

Koalisyon hükümetinin Türkiyedeki örneklerine baktığımızda, bu çerçevedeki ilk ortaklığın 1961 yılında Cumhuriyet Halk Partisi ile Adalet Partisi arasında kurulduğunu görmekteyiz. Bu birlikteliğin ardından, günümüze kadar çeşitli özelliklerde çok sayıda koalisyon hükümeti kurulmuştur. 1991 yılına gelindiğinde de bu çerçevede bir hükümet sistemi tercih edilmiş ve farklı görüşlerdeki DYP ile SHP, koalisyon kurma konusunda anlaşmışlardır. Söz konusu partiler tarafından kurulan hükümet, geniş bir temsiliyete ve uzlaşı kültürüne sahip olması nedeniyle, 1991-1996 yılları arasında görevde kalmıştır. Çeşitli siyasal gelişmelerin yaşandığı bu dönemde, basın alanında da önemli olaylar meydana gelmiş ve hükümetin basına dair kritik uygulamalarda bulunduğu görülmüştür. 
$\mathrm{Bu}$ bağlamda çalışmada, DYP-SHP/CHP koalisyon hükümeti yönetiminde, basına ilişkin yapılan yasal düzenlemeler ve basının genel durumu ele alınmıştır. Çalışmanın problemini, DYPSHP/CHP koalisyon döneminde basının özgür olup olmadığını ortaya koymak oluştururken, bu süreçte basın özgürlügünün ve çıkarılan yasaların hangi yönde şekillendiğini saptamak ise amacını oluşturmaktadır. Türk siyasal tarihindeki en uzun süren koalisyon hükümetinin basın özgürlüğü konusundaki tutumunu göstermek adına önemli olan çalışmada, yöntem olarak ise betimleme metodundan yararlanılmıştır. Bu doğrultuda çalışmada ilk olarak, araştırmaya zemin hazırlaması için demokrasi ve basın özgürlügü konuları ele alınmıştır. Ardından parti sistemlerine ve koalisyon hükümetine ilişkin bilgilere yer verilmiştir. Daha sonra ise DYP-SHP/CHP hükümetinin işleyişinin ve basına yönelik tutumunun anlaşılır kılınması adına bu dönemdeki siyasal, hukuksal, ekonomik ve toplumsal olaylar aktarılarak, basına dair yasal ve genel gelişmeler, basın özgürlüğü bağlamında tartışılmıştır.

\section{Demokrasi ve Basın Özgürlüğü}

Halkın kendi seçimlerinin bir sonucu olarak, yine kendisi tarafından yönetilmesi anlamına gelen demokrasi, halk ve yönetim gibi iki unsurun birleşimi temelinde ortaya çıkmaktadır (Heywood, 1997, s. 110). Bu bağlamda, halkın yönetecek kimseleri kabul etme veya reddetme hakkına sahip olması, demokrasinin en değerli kazanımı olarak göze çarpmaktadır (Schumpeter, 2007, s. 373). Çoğunluğun iktidarını kontrol altına alarak, azınlıkların haklarını ve menfaatlerini koruyan demokrasi, bu yönüyle hak ve hürriyet odaklı bir siyasi sisteme karşılık gelmektedir (Heywood, 2012, s. 102).

Demokrasi kavramının kelime kökeni, Yunanca'da demos (halk) ile kratos (güç-yönetim) sözcüklerinin birleşmesinden doğmaktadır (Çeçen, 2000, s. 58). İlk çağlarda toplumu oluşturan çoğunluğun basiretsiz ve istikrarsız bir egemenliği olarak tanımlanan demokrasinin, bir makama sahip olmayan bireylere yönelik kullanıldığı görülmüştür (Manfred, 2002, s. 28). Modern demokrasinin ortaya çıkışını, 18. yüzyılın sonlarındaki Amerikan (1776) ve Fransız (1789) Devrimlerinin yarattığı siyasete kadar götürmek mümkündür. Öyle ki 1787 yılında yazılan Birleşik Devletler Anayasası’yla, oy hakkı sadece mülkiyet sahibi olanlara verilse de ortaya demokratik bir sistemin çıkarıldığını söyleyebiliriz. Daha sonra, yönetimin halk egemenliğine dayandığı görüşünü ortaya atan Fransız Devrimi'nin ise daha radikal fikirlerin tartışılmasına zemin hazırlayarak, demokrasinin esas temelini oluşturduğunu savunabiliriz (Heywood, 1997, s. 109).

Ulaştığı nokta itibariyle, insan onurunun yüceltilmesini temel bir değer gören demokrasi, bireysel hak ve özgürlükleri de güvence altına almaktadır. Bu noktada, özgürlük ve hak tanımının çerçevesinin net bir şekilde çizilmesi önemlidir. Nitekim her talebin özgürlük olarak değerlendirilmemesi ve hak söz konusu olduğunda kazanımın gereği sorumlulukların da olduğunun özümsenmesi gerekmektedir (Ural, 1999, s. 2-3). Demokrasi kavramına ilişkin genel bir değerlendirmenin ardından, basın özgürlüğü ile demokrasi ilişkisini ele almak, çalışma açısından önem arz etmektedir.

Demokratik bir düzende basın, bireylerin haklarının korunması ve kendisini hür bir şekilde ifade edebilmesi için en etkili güçlerin başında gelmektedir. Ayrıca basının özgür olması, ülkenin 
gelişmişlik düzeyini gösterdiği için son derece değerli bir unsur olarak görülmektedir. Bu yönüyle, demokratik toplumlarda mevcut sistemin sağlıklı bir şekilde işleyebilmesi için bilgilerin dolaşımını sağlayarak önemli bir rol üstlenen basın, demokrasi zincirinin en kritik halkası olarak öne çıkmaktadır (Bülbül, 2001, s. 17). İçel ve Ünver’e (2009) göre basin özgürlüğü; gazete, televizyon, radyo, sinema ve internet gibi araçlarla haber, fikir ve bulguların, özgürlük çerçevesinde ele alınabilmesi ve söz konusu verilerin küresel ölçekte, hür bir şekilde paylaşllabilmesidir (s. 24).

Görüldüğü üzere, basın özgürlüğü, herhangi bir olayın öğrenilmesi kadar, özgürce dağıtımını da içeren bir haktır. $\mathrm{Bu}$ yönüyle, basın özgürlüğünün çerçevesinin gayet açık olmasına rağmen, basın alanına dair karar verici bir otorite olan siyasilerin, söz konusu unsur üzerinde hemfikir olmadığ 1 görülmektedir. Bu noktada, Fransız devlet adamı Napolyon; "Basın özgürlüğü mü? Asla... Bunu onlara verdikten sonra benim için yapılacak iş, bir arabaya binip çiftliğime gitmek ve artık orada yaşamaktır. Eğer basının dizginlerini elimden kaçırırsam, iktidarda üç aydan fazla kalamam” diyerek, siyasetçilerin basın özgürlügüne ilişkin genel bakış açısını net bir şekilde özetlemiştir (Bülbül, 2001, s. 19).

Bir diğer örnekte ise ABD’nin 3. başkanı olan Thomas Jefferson, "Hükümetsiz bir basını, basınsız bir hükümete tercih ederim" diyerek basına verdiği önemi göstermiş ve siyasilerin, baskıcı tutumunun aksi yönünde bir politika takip etmiştir. Ayrıca Jefferson’un öncülüğünde, Amerikan Anayasası̉nda basın özgürlüğüne yönelik ilk kalıcı düzenleme yapılmış ve mevcut hüküm ile basının özgürce faaliyetlerini yürütebilmesi demokratik sistemlerin vazgeçilmez unsuru olarak ifade edilerek anayasal güvence altına alınmıştır. Bu gelişmeler üzerine, Jafferson’un basın özgürlügüne katkılarından dolayı, Columbia Üniversitesi Gazetecilik Fakültesi’ne bir heykeli bile dikilmiştir (Bülbül, 2002, s. 88-89).

Günümüzde gelinen noktada basın, dördüncü bir güç olarak kabul görse de, basın özgürlüğünün eşdeğer öneme sahip olamadığı ve bu hürriyetin sağlanması için samimi adımların atılmadığı görülmektedir. Ancak basının içerik oluştururken karşılaştıkları sınırlandırma, hem içeriği üreten hem de olayların iç yüzünü öğrenmeye çalışan halk adına sorun oluşturmaktadır (Büyükbaykal, 2004, s. 43-44). Bu noktada, bireyin oy verirken doğru bir seçim yapabilmesi için yansız şekilde bilgilendirilmesinin önemine dikkat çekmek gerekmektedir. Bu işleyişin aksaması durumunda, demokrasi zincirinin en değerli halklarından olan basın, işlevini yitirmekte ve ortaya hak ihlali çıkmaktadır. Bu nedenle, yönetimde hangi sistemde ya da dünya görüşünde bir iktidar olursa olsun, düşünceyi açıklama ve basın özgürlüğünün güvence altına alınması büyük bir öneme sahiptir (Özek, 1999, s. 33).

Çalışma açısından önemli olan demokrasi ve basın özgürlüğü kavramlarına kısaca değindikten sonra, çalışmada ele alınan koalisyon hükümetinin daha iyi anlaşılması için parti sistemlerine ve çok partili sistem içinde değerlendirilen koalisyon hükümetine dair bilgi vermek faydalı olacaktır.

\section{Parti Sistemleri ve Koalisyon Hükümeti}

Toplumu oluşturan bireylerin hayatını düzenleyen kuralları hazırlama, muhafaza etme ve çağa uygun hale getirme kapsamında yürütülen çok yönlü bir süreç olan siyaset, ülkenin yarınlarının 
belirlenmesinde etkili bir sistem olarak öne çlkmaktadır (Heywood, 2012, s. 22). Bu yönüyle, yerel ve küresel birtakım değerleri içinde barındıran siyaset, derin kökler üzerine yükselmektedir. Siyasetin odak noktasında yer alan siyasal partiler ise hedeflere uygun olan bir program etrafında örgütlenen, iktidara sahip olmak veya ortaklaşa yürütmek hedefinde olan kuruluşlardır (Kapani, 2012, s. 176). Partiler, halkın desteğini arkasına alarak ülke genelinde örgütlü bir şekilde devamlllık gösteren ve aynı görüşü benimseyen kişilerden oluşan teşkilatlar halinde görev yapmaktadırlar (Şimşek, 2002, s. 32). En temel olarak, iktidar olabilmek için mücadele eden partiler, demokratik sistemin en değerli yapı taşları arasındadır (Gümüş, 2013, s. 176). Bir ulusun geleceğini belirleyen partilerin işlevlerini temsil etme, seçkin bir sınıf meydana getirme, bir amaç belirleme, çıarları ortaya koyma, sosyalleşme ve hükümet olma şeklinde sıralayabiliriz (Heywood, 2012, s. 325).

Söz konusu işlevlerin ve hedeflerin ise partilerin sistemlerine göre biçimlendiğini söylemek mümkündür. Bu yönüyle, yönetimin şekillenmesine doğrudan etki eden parti sistemleri ülkedeki politik, kültürel ve ekonomik düzen içinde oluşmaktadır (Öztekin, 2013, s. 115). Bu bağlamda, bir ülkede tek ya da çok partili sistemin olmasının ülkenin değerlerinin yansımasını oluşturduğunu söylemek mümkündür. Öyle ki, parti sistemleri rejimlerin arka planlarının ortaya çıkarılmasında büyük öneme sahiptir (Kışlalı, 1996, s. 238). Öte yandan, çeşitli özelliklerine göre değişiklik gösteren parti sistemleri arasında ayrıma gidilirken bunun çoğunlukla sayı kriteri üzerinden yapıldığı görülmüştür. Bu doğrultuda, en kabul gören ayrım ise, tek, iki ve çok partili sistem şeklinde yapılmıştır (Kapani, 2012, s. 194).

Tek partili sistem, bir ülkenin politikasını tek başına aldığı kararlarla yöneten ve başka bir güce olanak tanımayan siyasi oluşumdur. Söz konusu yönetimin olduğu yerde, parti ve devlet ilişkileri birbirine geçmiş durumdadır (Tunaya, 1995, s. 65). Siyasal ve anayasal olarak, iktidarın egemen olduğu sistemde, eşit rekabet şartlarından söz etmek mümkün değildir. Hep aynı partinin iktidar olduğu tek partili yapılarda, yasama ve yürütmede bir tekel hâkim olmaktadır (Özdemir ve Atılgan, 2014, s. 246).

Hükümet olma gücünü elde etmek için eşit şansa sahip, iki temel parti tarafından yönetilen iki partili sistemde iktidar, iki parti arasında sırayla paylaşılırken, diğer küçük partiler muhalefet partisi olarak görevlerini yürütmektedirler (Heywood, 2012, s. 335). İki partili sistemin kurulabilmesi ve doğru bir şekilde işleyebilmesi için ana sorunlar üzerinde hem fikir olunması gerekmektedir. $\mathrm{Bu}$ nedenle, söz konusu sistemde uzlaşma kültürünün olması son derece önemlidir (Teziç, 1997, s. 334).

Çok partili sistem ise çok sayıdaki siyasal partinin birbirini takip ettiği ve iktidar gücünü elde etme hakkına sahip olduğu düzendir (Kapani, 2012, s. 201). Bu sistemde hükümet, genel olarak seçim sonunda, partiler arasında yapılan pazarlıkların sonucunda ortaya çıkmaktadır (Kışlalı, 1996, s. 255). Çok partili sistemde tercih edilen bir hükümet yöntemi olan koalisyonu ise birden fazla partinin bir araya gelerek güvenoyu aldıktan sonra yürütme gücünü ortak kullanması şeklinde tanımlamak mümkündür. Bu noktada, siyasal gücün paylaşılmasının siyasal, toplumsal, ekonomik, kültürel ve birçok alanda etkili olduğunu söyleyebiliriz (Tutar, 2007, s. 16). Söz konusu yöntemde, ortaklığın yapısına da bağlı olmakla birlikte, koalisyon hükümetlerinin genel itibariyle kısa süreli olduğu görülmektedir. Buna ilaveten koalisyonlar, farklı değerlere sahip siyasal partiler tarafından 
oluştuğu için net bir hükümet programı çıkarmak zorlaşmaktadır (Duverger, 1986, s. 42). Bu noktada koalisyonlara yönelik eleştiriler, söz konusu sorunlar üzerinden yapılırken, koalisyonun güçlü yanının ise uzlaşmacı zemin üzerine yükselmesinde gizli olduğunu söyleyebiliriz (Heywood, 2012, s. 339). Öyle ki bu hükümetlerde özgürlük, siyasal partiler için en değerli kavramlar arasında yer alırken, partilerin hiçbir şekilde engellenmediği görülmektedir. Öte yandan siyasi partiler arasında, eşitsizlik olmadığını da söylemek mümkündür (Öztekin, 2013, s. 117). Nihayetinde; özgürlük, insan hakları ve eşitlik gibi ana ilkeler üzerinde hassas olan koalisyon hükümetlerini, parti sistemleri arasındaki en demokratik yapılar olarak değerlendirebiliriz.

Çalışmada ele alınan hükümet yapısının kavramsal açıdan aktarılmasının ardından 1991 ve 1996 yılları arasındaki DYP-SHP/CHP koalisyonu döneminde yaşanan siyasal, ekonomik, hukuki ve toplumsal olaylara yer verilecektir.

\section{DYP-SHP/CHP Koalisyon Hükümeti (1991-1996 Dönemi)}

20 Ekim 1991 tarihinde yapılan seçimde DYP \%27 oranında oy alarak ANAP'ın tek başına kurduğu hükümete son vermiş ve 1990 ’lı yıllardaki koalisyon zincirinin ilk halkasını oluşturmuştur. Oyların \%24'ünü alan ANAP ikinci parti olurken RP \%16,9, DSP ise \%10,8 oranında oy alarak meclise girmiştir (Kejanlıoğlu, 2004, s. 345). Seçimdeki en dikkat çekici parti, yaklaşık \%17 oranında oy alarak mecliste kendine yer bulan RP olmuştur (Zürcher, 2011, s. 421). Bu sonuçlara istinaden, $\% 48$ oranındaki bir temsiliyete karşılık gelen DYP-SHP koalisyonu kurulmuş ve 20 bakanlık DYP'ye, 12 bakanlık ise SHP’ye verilmiştir. Uzun süredir iktidar olamayan iki farklı görüşün birlikteliği olan bu hükümet, 1961'de CHP ile AP arasında kurulan ilk koalisyona benzetilmiştir. Bu nedenle, DYPSHP/CHP koalisyon hükümeti ülkedeki kutuplaşmanın sonlandırılması adına büyük bir umut olmuştur (Tutar, 2007, s. 294-297).

Beklentilere cevap vermek için demokratikleşmeyi temel hedef olarak belirleyen koalisyon, huzuru ve kalkınmayı sağlamayı da amaç edinmiştir (Kara, 2004, s. 229). Bu bağlamda, hükümet programında insan hakları ve özgürlüklere dayalı bir hukuk devleti kurulacağına, yurttaşlara verilen hak ve özgürlüklerin kullanmasının ve geliştirmesinin doğallığına dikkat çekilmiştir (Çavdar, 2013, s. 312). Programında demokratikleşme, insan hakları, basın özgürlüğü, üniversitelere özgürlük gibi vaatlerde bulunan hükümet, temelde bu görüşler üzerinden hareket etse de ilerleyen süreçlerde söz konusu unsurları sağlamaktan uzak bir politika izlemiştir (Zürcher, 2011, s. 421).

Siyasi gelişmeler yönünden oldukça hareketli geçen bu süreçte, 17 Nisan 1993 tarihinde Turgut Özal'ın ölmesinin ardından Süleyman Demirel yeni cumhurbaşkanı olmuştur. Bunun üzerine Tansu Çiller DYP’nin başına geçmiş ve Türkiye’nin ilk kadın başbakanı olarak yönetimi devralmıştır. Böylece birlikteliğin ikinci dönemi başlamıştır (Lewis, 2010, s. 24). 25 Haziran'da SHP ile koalisyon kuran Çiller güvenoyu almak üzereyken, 2 Temmuz 1993 tarihinde Sivas Katliamı gerçekleşmiştir. Protestocu kalabalığın Madımak Oteli’ni ateşe vermesi sonucunda, Pir Sultan Abdal Etkinliklerỉne katılmak için Sivas'ta bulunan sanatçı grubundan 35 kişi yanarak can vermiştir. Söz konusu olayda Süleyman Demirel, devlet ile halkın karşı karşıya gelmemesinin önemini vurgulamış, Tansu Çiller ise otelin etrafında yer alan vatandaşlara bir şey olmadığını belirtmiştir. Bu katliamın ılımlı ifadelerle 
geçiştirilmesi ve olayı düzenleyenlerin "halk" olarak anılması ise büyük bir tepkiye neden olmuştur (Akşin, 2007, s. 293).

Ülke genelindeki huzursuz ortam gitgide artarken, siyasi alanda SHP ve CHP’nin birleşmesi gündeme gelmiş ve görüşmeler sonucunda partiler, 6 Kasım 1994 tarihinde birleşmişlerdir. Sonrasında, 28 Ocak 1995’te CHP Kurultayı düzenlenmiş ve uzun tartışmaların sonucunda Hikmet Çetin’in liderliği üzerinde uzlaşılmıştır. Bu gelişmeler sonrasında hükümet, DYP-CHP koalisyonu olarak faaliyetlerine devam etmiştir (Tutar, 2007, s. 325-327).

Söz konusu dönemin genelinde, en temel sorunlar arasında terör olayları yer almış ve ülke genelinde huzursuzluk hâkim olmuştur. Birçok polis ve sıkıyönetim yetkilisinin öldürüldügü bu süreçte işkenceler artmış ve Güneydoğu'da görev yapan kişiler hedef haline gelmiştir. Ülkedeki söz konusu huzursuzluklara ilaveten, ekonomi alanında da krizler yaşanmıştır. Bu süreçte, enflasyonun yükselmesi önlenemezken, işsizlik ve gelir dağılımındaki sorun çözülememiştir (Çavdar, 2013, s. 314320). Öte yandan bankaların iflas ettiği bu dönemde, faizler \%95’i görmüş ve borsada büyük düşüşler yaşanmıştır. Dövizle borçlanan şirketler batarken, dövize yatırım yapanlar ise büyük kazançlar elde etmişlerdir (Tutar, 2007, s. 322).

Nihayetinde, 1996 yılına kadar süren koalisyon, ilk başlarda olumlu adımlar atsa da uzun vadede beklentileri karşılayamamış ve ekonomik, hukuki, siyasi ve toplumsal krizlerin yaşanmasına neden olmuştur. Ülkedeki huzur ortamını da sağlayamayan DYP-SHP/CHP koalisyon hükümeti, terör olaylarının önüne geçememiş ve çok sayıda kişinin öldürülmesini engellemek için çözüm üretememiştir. Bu nedenle, söz konusu koalisyon dönemini Türkiye’nin en karmaşık süreçlerin biri olarak değerlendirmek mümkündür.

\section{DYP-SHP/CHP Koalisyon Hükümeti Döneminde Basın Özgürlüğü}

1990’ların başında kurulan DYP-SHP koalisyonu, farklı liderler üzerinden olsa da uzun süre yönetimde kalmış ve aldığı radikal kararlarla basın alanında dönüşüme neden olmuştur. Özelleştirme, baskı, denetim, şiddet, terör, hapis ve para cezaları üzerinden şekillenen bu süreçte, basına ilişkin birçok tartışmalı uygulamada bulunulmuş ve basın özgürlüğüne yönelik ihlaller dikkat çekmiştir. Ancak söz konusu hükümetin, iktidarının ilk zamanlarında aksi bir yaklaşım içinde olduğu ve politikalarını özgürlükçü bir felsefe üzerinden kurguladığı görülmüştür.

Bu bağlamda, kurulduğu yıllarda basın sorunlarının çözülmesi noktasında önemli vaatlerde bulunan koalisyon, 25 Kasım 1991 tarihinde hükümet programında, Başbakan Süleyman Demirel önderliğinde şu mesajları vermiştir:

Laik ve Atatürk ilkelerine bağlı Türkiye'de; inanç, düşünce, anlatım özgürlükleri toplumun temelidir, kısıtlanamaz. Hükümet, çağdaş akım ve gelişmelere paralel bir basın özgürlüğü anlayışını kesinlikle oluşturmak ve uygulamaya koymak kararındadır. Halkımıza, gerçekleri yansıtan ve doğru haber alma olanağı sağlayan tarafsız bir devlet radyo-televizyonu mutlaka sağlanacak ve özel televizyon ve radyo istasyonlarının da kurulmasına olanak veren hukuksal ortam hazırlanacaktır. Bu amaçla hükümet, bunun gereği olan anayasa 
değişikliklerini sağlamaya çalışacak ve anayasa değişikliğini gerekli kılmayan düzenlemeleri gerçekleştirecektir. Ülkemizin her yanında terör önlenecek, yurttaşların can güvenliği ve huzuru sağlanacaktır. Siyasi cinayetlerin son bulması, faillerin yakalanması devletin önemli görevlerinden biridir. Sansür, Muzır ve Basın Yasası gibi yasalardan kaynaklanan kısıtlayıcı düzenlemeler ise yaratıcıllğı özgürleştirmek ve hükümetimizin temellendirmeye çalıştığı demokratikleşme ülküsünü hızlandırmak için kaldırılacaktır. (Neziroğlu ve Yılmaz, 2013, s. 6570-6592)

Konuşmadan anlaşılacağı üzere hükümet, özgürlükçü adımların atılacağını ifade etmiş ve hukukun üstünlüğüne, demokratik sistemin temel değerlerine verdikleri öneme ilişkin söylemlerde bulunmuştur (Kara, 2004, s. 231). Umut verici bir şekilde ilerleyen hükümet, siyasal özgürlügü sağlama ve basın alanında yapılacak değişiklerle heyecan yaratmıştır. Özellikle radyo ve televizyonun özelleştirilmesi ile devlet tekeline son verilmesi yönünde çalışmaların olabileceğinin belirtilmesi önemli bir gelişme olarak görülmüştür. Nitekim bu bağlamda, Devlet Bakanı Gökberk Ergenekon'dan 29 Mart 1992 tarihine kadar taslak hazırlanması istenmiştir (Çatalbaş, 2017, s. 495). Ancak bu süreçte, Magic Box isimli özel bir televizyon yayın hayatına başlamış ve söz konusu yayının durumu büyük bir tartışma yaratmıştır. Bunun üzerine, meclise araştırması için 29 Eylül 1992'de önerge verilmiştir. 15 Mart 1993 tarihine gelindiğinde ise İçişleri Bakanlığı, radyo frekanslarının telsiz iletişiminde güvenlik sorunu yaratması nedeniyle, yasa dışı radyo ve televizyonların kapatılması için bir genelge yayınlamıştır (Asker, 2017a, s. 644). Bu kapsamda, Ulaştırma Bakanı Yaşar Topçu özel yayınların anayasaya aykırı olduğunu ifade ederek, valilere 24 saat içinde yayınların kapatılması gerektiğini bildirmiştir. Bu kararın gerçek nedeni, her ne kadar dini içerikli ve Kürt haklarını savunan yayınları engellemeye yönelik olsa da söz konusu kararla, bütün özel radyo ve televizyonların yayınına son verilmiştir. Halk tarafından demokrasi ile bağdaşmayan bir karar olarak görülen gelişme üzerine, ülke genelinde "Radyomu İstiyorum” eylemleri yapılmıştır (Duran, 2012, s. 27).

Basın özgürlügü ve demokrasi vaatleri ile iktidara gelen hükümetin, özel yayınlar üzerindeki hamlesiyle tartışmalı bir karara imza attığını söyleyebiliriz. Söz konusu yıllar için "sakıncalı” olarak görülen, dini içerikli ve Kürt haklarını savunan yayınların önüne geçebilmek adına yapılan müdahale, hükümetin dönemin ruhuna uygun bir tutum içinde olduğunu göstermektedir.

Koalisyon hükümetinin ilk dönemi böyle geçerken, Cumhurbaşkanı Özal’ın vefat etmesi üzerine Demirel cumhurbaşkanı seçilmiş ve Tansu Çiller başbakan olmuştur. Yirmisi DYP'den, on ikisi SHP'den olmak üzere yeni bir kabine kuran partiler, yeniden ortak bir şekilde hareket etmiş ve 5 Temmuz 1993 tarihinde güvenoyu almıştır (Topuz, 2015, s. 297). Yeni kurulan koalisyonun protokolünde ise basın özgürlüğüne ilişkin şu ifadeler kullanılmıştır:

Temel hak ve özgürlükler sağlam güvencelere bağlanacaktır. Kişinin hakları genişletilecek ve güvenceleri artırılacaktır. Sosyal ve ekonomik haklar, başta sendikal haklar ve toplu sözleşme ve grev hakkı olmak üzere çağdaş demokrasi ve ILO standartlarına yükseltilecektir. Basın özgürlüğü ile yurttaşın gerçek, doğru ve çoğulcu bilgi alma hakkı güçlendirilecektir. Radyo ve TV yayınları üzerindeki devlet tekeli kaldırılacaktır. Düşünceyi yayma özgürlüğü genişletilecek, toplama, yasaklama, ağır cezalar uygulama gibi kısıtlamalar, demokrasilerdeki standartlara ulaştırılacaktır. (Neziroğlu ve Yılmaz, 2015, s. 1080-1822) 
Yukarıdaki metinde de belirtildiği üzere, ilk iş olarak 8 Temmuz 1993'te anayasanın 133. maddesi değiştirilmiş, radyo ve televizyon üzerinde olan devlet tekeline son verilmiştir. Böylece, 1991 yılından beri engellenen radyo ve televizyonların üzerindeki yasak kaldırılmıştır. Bu gelişmeden sonra, 4 Kasım 1993 tarihinde Avrupa Sınır Ötesi Televizyon Sözleşmesi’ni onaylayan hükümet, 13 Nisan 1994 tarihinde ise radyo ve televizyon yayınlarını düzenleyen, 3984 Sayılı Kanunu yürürlüğe koymuştur (Asker, 2017a, s. 649). Söz konusu yasa kapsamında, meclisteki partilerin gösterdiği adaylar arasından seçilen RTÜK göreve başlamıştır (Tokgöz, 2015, s. 51). Bu sistem ile radyo ve televizyonlar üzerinde sıkı bir denetim kurulmuş ve yayınları durdurma ve kapatma hakkı yasal olarak sağlanmıştır (Birol, 2018, s. 66).

Hükümet, koalisyonun ikinci döneminde vaatlerin bir kısmını gerçekleştirmiş ve basın özgürlüğünü sağlamak adına devletin egemenliğinde olan yayıncılığı serbest hale getirmiştir. Bununla birlikte, yeni yayınlar ortaya çıkmış ve çeşitli görüşler tartışılmaya başlanmıştır. Bu yönüyle, son derece değerli bir adım olan bu karar, daha sonrasında farklı yasal düzenlemelerle törpülenmiş ve basın alanında sert bir denetim sistemi ortaya çıkmıştır. Özellikle azınlık olan görüşler üzerinde çeşitli cezalar uygulanmış ve basının çok sesliliği ortadan kaldırılmaya çalışmıştır.

Bir süre sonra ise siyaset ile İstanbul basını arasında dengeler değişmiş ve çıkarlar üzerinden yeni bir ilişki biçimi kurulmuştur. Bu süreçte, devletin olanaklarını elinde bir "sopa” olarak kullanan hükümet, medyayı ekonomik yönden baskı altına almış ve baskı düzeni ortaya çıkarmıştır (Tokgöz, 2015, s. 51). Öyle ki bu dönemde, kulislerde Çiller’in kendi çıkarları için devlet tarafından verilen teşvikleri medyaya ayrıcalıklı olarak aktardığı söylentileri dolaşmaya başlamıştır (Asker, 2017a, s. 647). Bu tartışmaların odak noktasında yer alan teşviklerin tutarlarını ise şu şekilde sıralamak mümkündür: "Sabah: 699 milyar 263 milyon TL, Hürriyet: 425 milyar 570 milyon TL, Milliyet: 334 milyar 683 milyon TL, Türkiye: 229 milyar 646 milyon TL, Zaman: 49 milyar 551 milyon TL.” (Topuz, 2015, s. 355-356).

Hükümetin kendisine yakın olan yayınlara yönelik sunduğu imkânlar sonrasında basında kutuplaşmalar başlamıştır. Bu süreçte gelinen noktada halk, 1995 seçimleri öncesinde birbirine hangi gazeteye oy vereceğini sorar hale gelmiştir. Öte yandan bu dönemde ANAP Genel Başkanı Mesut Yılmaz, Sabah gazetesi Genel Yayın Yönetmeni tarafından şantaja maruz kaldığını belirtmiştir. Medyanın, Tansu Çiller tarafından satın alındığını söyleyen Yılmaz, Çiller’in eşinin ne yazıp yazılmaması konusunda gazeteleri aradığına dikkat çekmiştir. Buna karşılık olarak, banka reklamlarının ise uyarıyı dikkate alan yayınlara verileceğini vurgulamıştır (Tılıç, 2009, s. 297-298).

Görüldüğü üzere, basın ve siyasiler arasında dönüşüme uğrayan ilişkiler, kısa süre sonra çıar odaklı bir hal almaya başlamıştır. Basının değerlerinin görmezden gelindiği bu dönemde hükümet, basını siyasal çıkarlarına alet etmiş ve gücünü pekiştirmek adına maddi olarak baskı altına almıştır. Devletin olanaklarını kullanarak, basın için çeşitli çıkarlar sağlayan hükümetin kendisine yakın olan gazete ve gazetecileri ödüllendirirken, muhalif basını ise cezalandırdı̆̆ı görülmüştür.

$\mathrm{Bu}$ yıllarda yaşanan bir başka sorun ise sendikasızlaştırma yönünde atılan adımlar olmuştur. Sendika oranının düşük olduğu bir ortamda, sendikaya bağlı gazeteciler istifa etmesi yönünde zorlanmıştır. Buna karşılık, yeni sistemdeki birtakım gazetecilere ise yüksek ücretlerin ödendiği 
görülmüştür. Gelinen noktada, maaş konusunda ayrımc1lık ve emek sömürüsü sorunları ortaya çıkmıştır (Tokgöz, 2015, s. 54). Daha sonraları ise gazetecilere çeşitli güvenceler tanıyan 212 sayılı yasa da önemini yitirmiş ve sendikalar devre dışı bırakılmıştır (Özsever, 2004, s. 111).

Böylece basının sermayesindeki ve içeriğindeki dönüşümle birlikte, gazetecilerin hakları da ellerinden alınmıştır. Yaşanan gelişmeler üzerine, gazeteciler işten çıkarılmış ve basın hürriyetinin temel değerleri arasında yer alan gazeteci hakları, patronların ve siyasetçilerin çıkarlarına göre şekillenir hale gelmiştir.

DYP-SHP/CHP koalisyonu döneminde, Kürt meselesi de oldukça ciddi bir krize dönüşmüştür (Kara, 2004, s. 247). Öyle ki bu süreçte, Doğu bölgelerindeki çatışmalar ülke genelinde huzursuzluğa neden olmuş ve çok sayıda faili meçhul eylem yaşanmıştır (Kejanlıoğlu, 2004, s. 349). Bu yıllarda emekli komutanları öldürmeye başlayan PKK, sivil halk arasında kayıpların yaşanmasına neden olmuştur. Bunlarla birlikte, ülkenin önde gelen gazeteci ve yazarlarına yönelik saldırılar da görülmüştür (Duran, 2012, s. 50). Bu doğrultuda, 23 Mart 1992 tarihinde İzzet Keser ve 20 Eylül 1992 tarihinde Musa Anter öldürülürken, 24 Ocak 1993 tarihinde ise Uğur Mumcu öldürülmüştür (Topuz, 2015, s. 284-285). Başbakan Demirel ve İçişleri Bakanı İsmet Sezgin, bu ölümlerin devletle ilgili olmadığını savunurken, yaşanan olayların PKK ile bağlantılı kişilerce yapıldığını belirtmişlerdir. Ancak 1993 yllında gazeteci ölümleri üzerine bir araştırma yapan Andrew Yurkovsky, bu olaylarla devletin ilişkili olduğunu ve PKK’nın farklı olaylarla bağlantılı olduğunu öne sürmüştür. Yaşanan gelişmeler üzerine, 1992 yılının Haziran ayında Basın Konseyi, Başbakan’a açık bir mektup göndermiş ve Türkiye’nin gazeteci cinayetleriyle meşhur olan Kolombiyảnın da önüne geçeceğini iletmiştir. Daha sonrasında ise 1994 yılının Ocak ayında bir rapor yayınlayan konsey, 1993 yılını basın açısından kara bir yıl olarak ilan etmiş ve bu süreçte 51 gazetecinin saldırıya uğradığını, 8 gazetecinin yaşamını yitirdiği belirtilmiştir. Bu saldırıların 16'sı güvenlik kuvvetleri, 4'ü kamu görevlileri, 7’si ise bazı partilerin üyelerince yapılmıştır. Gazete ve dergilerin, 7 kez saldırıya uğradığı dönemde, polis gazetelere 15 defa baskın yapmıştır. Bu süreçte 95 gazeteci gözaltına alınırken, 49 gazetecinin ise tutuklandığ 1 görülmüştür. Yaşananlar üzerine, Uluslararası Gazeteciler Federasyonu Türkiye’yi dünyanın en çok gazeteci öldürülen ülkesi olması nedeniyle gazeteciler için dünyanın en riskli ülkeleri arasında göstermiştir. Gazetecileri Koruma Komitesi ise 1992 yllında Türkiye’yi, 9 gazetecinin öldürüldüğü, iç savaş halindeki Yugoslavya'dan daha tehlikeli bir ülke olarak raporlamıştır (Tilıç, 2009, s. 294-295).

Çağdaş Gazeteciler Derneği’nin hazırladığı raporda ise bu yıllar, askeri rejimler altında yönetilen bir süreç olarak değerlendirilmiş ve basın özgürlügünün oldukça sert bir şekilde sınırlandırıldığına dikkat çekilmiştir. Rapordaki verilere göre, 1992 yılında 57 gazeteci tutuklanmıştır. 36 gazeteci için açılan davalar sonucunda toplam, 229 yıl 4 ay hapis cezası verilirken, 16 gazeteci için 124 milyar para cezası uygulanmıştır. Ayrıca 17 gazeteci ve yayın kuruluşu için, 193 milyar 465 milyon lira tazminat istenmiştir. Basın Konseyi’nin verilerine göre ise 1991'den 1993’e kadar 15’i silahlı, 3’ü bombalı olmak üzere 309 gazeteci saldırıya uğramıştır (Topuz, 2015, s. 280-281). 1994 yllında ise öldürme olaylarında azalma görülse de gazetecilere baskılar devam etmiştir. Öyle ki, İstanbul Devlet Güvenlik Mahkemeleri’ndeki davaların \%41'i basına yönelik açılırken, gazetecilere toplamda, 448 yıl 6 ay 25 gün hapis ve 2 milyon 400 dolar para cezası verilmiştir. Ayrıca 76 gazeteci ise görev başındayken, güvenlik kuvvetlerince dövülmüş ve çeşitli hakaretlere maruz kalmıştır (T1lıç, 2009, s. 295). 
Ülkedeki terör olayları ve gazetecilere yapılan saldırılar karşısında önlem almayan hükümet, basına yapılan eylemlerin arkasında kimlerin olduğunu da araştırmamıştır. Bu nedenle hükümet, ülke içinden ve dışından birçok kuruluşun tepkisini çekmiştir. Çeşitli yerel ve uluslararası kuruluşlar tarafından sıklıkla kınanan koalisyon yönetimi, özgürlük temelli olan söz konusu otoritelerin çă̆rısına sessiz kalmıştır.

Öte yandan bu süreçte, Terörle Mücadele Kanunu'nun 8. maddesi nedeniyle 5404 kişi yargılanmıştır. Bunun sonucunda, 765 kişiye 114 milyar 307 milyon para cezası ve 557 yıl hapis cezası verilmiştir. 1994 yılının sonlarına doğru ise gazeteci-yazar Onat Kutlar, PKK tarafından bir otelin pastanesine yerleştirilen bombanın patlaması sonucunda yaralanmış ve 11 Ocak 1995 tarihinde hayatını kaybetmiştir. Yeni Günaydın gazetesinin sahibi Bekir Kutmangil, 23 Mayıs 1995 tarihinde yaşamını yitirirken, Son gazetesinin sahibi olan Nail Aydın 30 Temmuz 1995’te öldürülmüştür. Yeni Politika gazetesinin muhabiri olan Seyfettin Tepe ise gözaltına alındığı Bitlis Emniyet Müdürlügü̉nde 30 Ağustos 1995 tarihinde ölü olarak bulunmuştur. Türkiye İnsan Hakları Vakfi’nın verilerine göre, dört yıllık süreçte 2689 kişi işkence sonucunda ölmüştür. Öte yandan Uluslararası Basın Enstitüsü düzenlediği toplantıda, 1995 yılının Ocak ve Şubat aylarında 1260 yayına el konulduğunu, Şubat ayı sonunda, 103 gazeteci ve yazarın hapiste olduğunu açıklamıştır. Bunlara ilaveten, 1995 yılının Ekim ayında ise DGM'lerdeki dava sayısının 6091, tutuklu yargılananların 6975, tutuksuz yargılananların 16917 kişi olduğu görülmüştür (Topuz, 2015, s. 304-305).

Ülkedeki güvensiz ortamın önüne geçebilmek adına yasal uygulamalara başvuran hükümet, Terörle Mücadele Kanunu kapsamında çözüm üretmeye çalışmıştır. Ancak bu düzenleme ile basın alanında sert müdahalelerde bulunulmuş ve basın kuruluşlarına ve gazetecilere ağır cezalar verilmiştir. Bu noktada, basının şiddet, ölüm ve çeşitli cezalar üzerinden sıkı bir şekilde baskı ve denetim altında tutulduğunu söylemek mümkündür.

DYP-SHP/CHP koalisyonunda Kürt basınına yönelik yapılan baskıları ise ayrıca ele almak gerekmektedir. Tılıç’a göre (2009), bu yıllarda Kürt hakları savunucusu basın üzerinde yoğun bir baskı hâkim olmuştur. Bu süreçte, Özgür Ülke gazetesinin İstanbul ve Ankara’daki büroları 3 Aralık 1994’te bombalanmış ve bir kişi hayatını kaybetmiştir. Saldırının, 30 Kasım 1994'te "gizli” ibareli Çiller'in imzasını taşıyan yazının kurumlara sevk edilmesinden sonra olması ise dikkatleri çekmiştir. Bu gelişmeler üzerine, 1995 'te basının en büyük düşmanı listesini yayınlatan Gazetecileri Koruma Komitesi, öncelikle Tansu Çiller’i, 1996 yılında ise Mesut Yılmaz’ı listeye dâhil etmiştir (s. 296).

Öte yandan bu süreçte, Kürt milliyetçiliği yapan Özgür Ülke, Özgür Gündem ve Yeni Politika gazetelerinin yayın faaliyetleri ise sonlandırılmıştır. Özellikle dönemin en çok tartışılan konularından biri olan Terörle Mücadele Kanunu üzerinden, çok sayıda gazeteci, ağır cezalara çarptırılmış ve birçok gazete kapatılmıştır. Bu bağlamda; İsmail Beşikçi, Fikret Başkaya, Haluk Gerger ve Münir Ceylan gibi gazeteciler hapse mahkûm edilenler arasında yer almaktadır (Duran, 2012, s. 23).

1995 yılındaki seçimlerden önce ise basın üzerinde yoğun baskı yaratan Terörle Mücadele Kanunu'nun 8. maddesi düzenlenmiş ve güncellenen hüküm şu şekilde ifade edilmiştir: "Devletin ülkesi ve milletiyle bölünmez bütünlügünü hedef alan yazılı, sözlü propaganda suçtur.” Ayrıca 13. madde kapsamında cezaların ertelenmesine ya da paraya çevrilmesine olanak tanınmıştır (Asker, 
2017b, s. 680). Düzenleme ile ülkede az da olsa bir özgürlük havası oluşmuş ve daha önceki maddeye istinaden hapiste bulunan 100 kişi serbest bırakılmıştır. Buna ilaveten, insan hakları ve demokratikleşme adına da bir adım daha atan hükümet, İnsan Haklarından Sorumlu Devlet Bakanlığı uygulamasını hayata geçirmiştir (Duran, 2012, s. 24). Söz konusu kararların alınmasında, hükümetin Avrupa Birliğine girme çalışmaları etkili olurken, bu çerçevede basın özgürleşmeye başlamış ve çeşitli konular tartışılır hale gelmiştir. Bu kapsamda, ifade özgürlügünün kapsamları genişletilmiş ve basılı yayınlardaki ön denetime son verilmiştir (Hawks, 2002, s. 48).

Söz konusu koalisyonu değerlendiren Duran’a (2012) göre, demokrasi vaatleriyle hükümeti kuran partiler başlarda engelleri kaldırsa da basın özgürlüğü, Kürt meselesi ve huzurun sağlanması konularında çeşitli krizlerin yaşanılmasına neden olmuşlardır (s. 10). Tokgöz’e (2015) göre ise bu yıllarda ülkedeki baskıcı ortama ilaveten, özelleştirme politikaları da bir adım öteye taşınmıştır. Tekelleşmenin bütün boyutlarıyla yaşandığı bu dönemde, reklam ve reyting kaygıları öne çımış ve gazeteciliğin değerleri görmezden gelinmiştir. Gazeteci aileleri ortadan kalkarken, basın içerik yönünden olduğu gibi fiziki olarak da dönüşmüş ve basın kuruluşları, İkitelli ve Güneşlideki yeni medya binalarına taşınmıştır. Bu süreçte, editoryal ve finansal açıdan köklü bir değişim yaşayan basının, gazeteciliğin değerlerini de Babıalide bıraktığı görülmüştür (s. 49).

\section{Sonuç}

1991 yılında göreve başlayan DYP-SHP/CHP koalisyonu, sağ ve sol merkez partiler arasında kurulması ve uzun bir dönem yönetimde kalması nedeniyle, Türk siyasi tarihinde önemli bir yere sahiptir. Söz konusu ortaklık döneminin basına dair karnesine baktığımızda, ilk döneminde özgürlük vaatleriyle hükümeti kuran koalisyonun bir süre sonra özel yayınlara son vererek, basın özgürlüğ̈nü kısıtladığı görülmektedir. Özellikle dini içerikli ve Kürt haklarını savunan yayınlarının önüne geçmek için yapılan bu hamle ile hükümet, basın alanında baskıcı ve denetimci bir hava yaratmıştır.

1993 yllında koalisyonun ikinci döneminde ise bu kez devlet tekeline son verilmişve özel yayıncllık özgür bırakılmıştır. Bu bağlamda, bazı yasal değişikliklerde bulunan hükümet, kanunlar çıkararak gazete, radyo ve televizyon üzerinde kritik kararlar almış ve kitle iletişim araçlarının dönüşmesinde rol oynamıştır. Basın kuruluşlarının yapısına ilişkin yapılan yasal düzenlemelerin sonucunda basın, medya gruplarına dönüşmüştür. Bunun üzerine, gazeteci kökenli aileler ellerindeki yayın kuruluşlarını çıarmak zorunda kalmış ve basın alanına yeni patronlar dâhil olmuştur. Söz konusu durum, gazetecilerin çalışma koşullarında, haklarında ve özgür bir şekilde haber yapabilmelerinde sorunlara neden olurken, gazetecilik faaliyetlerinin medya patronlarının siyasi ve finansal çıarları etrafında şekillenmeye başladığı görülmüsstür.

Basındaki yapısal dönüşüme ek olarak, bu dönemde basının şiddetli bir baskıya maruz kaldığı da görülmüştür. Çok sayıda gazetecinin saldırıya uğradığı ve öldürüldüğü bu süreçte, aynı zamanda basın kuruluşları maddi yönden ağır cezalar ödemek zorunda kalmıştır. Bu yönüyle, baskıcı bir hükümet olarak ifade edebileceğimiz DYP-SHP/CHP koalisyonu, basın özgürlügünün sınırlandırıldığı bir süreç olarak öne çıkmıştır. Özellikle Atatürkçü ve Kürt haklarını savunan gazeteci ve basın kurumlarına yönelik saldırı ve baskıların arttı̆̆ı bu dönemde, birçok gazeteci hapse atılmış 
ve çok sayıda faili meçhul cinayet yaşanmıştır. Öte yandan Doğu bölgelerinde ise anarşi ve terör olayları artmış ve birçok kişi hayatını kaybetmiştir. Söz konusu gelişmeler yaşanırken, hükümetin baskıyı ve denetimi arttırmayı tercih ettiği ve yaşanılan sorunların artmasına sebebiyet verecek yasal uygulamalara başvurduğu görülmüştür.

Demokrasi, özgürlük ve insan hakları karnesi, inişli ve çıkışlı bir çizgide ilerleyen koalisyon döneminde, son yıllarda Avrupa Birliği’ne girmek amacıyla ise ılımlı adımlar atılmıştır. Bunun üzerine, baskıcı ve şiddete dayalı uygulamalar azalmaya başlamış ve hapisteki gazeteciler özgürlüklerine kavuşmuştur. Ancak bu tutumu, genele yayamayan koalisyonun, basına yönelik özgürleştirici uygulamalarını, iktidarının ilk ve son yılları ile sınırlandırdığı görülmüştür. Bu nedenle, DYP ile SHP arasında başlayıp, DYP ile CHP arasında sonlanan koalisyon döneminde, basının ağır koşullar altında çalıştığını söylemek mümkündür. Nitekim gerek yerel gerekse uluslararası basın örgütleri de bu süreci, Türk basını adına kara bir dönem olarak değerlendirmiş ve basın emekçilerine yönelik baskıcı ortamdan dolayı iktidarı kınamışlardır.

Sonuç olarak, ilk zamanlarda basın özgürlüğü, demokrasi, eşitlik ve insan hakları üzerine vaatleri olan hükümetin, söz konusu unsurları sağlamada başarılı olamadığı ve basın alanında otoriter bir yönetim sergilediği görülmüştür. Siyasi, ekonomik, hukuki ve toplumsal krizlerin çözümü noktasında da etkisiz kalan hükümet, bu problemleri tersine çevirmek yerine denetimi ve baskıyı arttırmayı seçmiş ve basın üzerinde çok ciddi hak ihlalleri yapmıştır. Bu noktada, koalisyon hükümetlerinde olması gereken temel şartları göz ardı eden hükümetin antidemokratik bir tutum içinde olduğunu söyleyebiliriz. Tüm bu tartışmalar ve bulgular çerçevesinde, DYP-SHP/CHP koalisyon hükümetinin basın özgürlügünü sağlama konusunda başarısız olduğu ve çıkardığı yasalarla, basını ve basın emekçilerini, olumsuz bir yönde etkilediği sonucuna varılmıştır.

\section{Kaynakça}

Akşin, S. (2007). Kısa Türkiye tarihi. İstanbul: İş Bankası Yayınları.

Asker, A. (2017a). Basının denetimi: Öncü ve BTV. K. Alemdar (Haz.), Türkiye’de kitle iletişimi dün-bugün-yarın cilt-I içinde (s. 644-673). Ankara: Gazeteciler Cemiyeti Yayınları.

Asker, A. (2017b). Gazeteci milletvekilleri: 1980-2009. K. Alemdar (Haz.), Türkiye’de kitle iletişimi dün-bugünyarın cilt-I içinde (s. 674-718). Ankara: Gazeteciler Cemiyeti Yayınları.

Birol, S. (2018). 1980 sonrası Türk medyasında sermaye yapısının el değiştirmesinin basında köșe yazarlğı̆na etkisi. Yayımlanmamıș Doktora Tezi. İstanbul: İstanbul Üniversitesi Sosyal Bilimler Enstitüsü.

Bülbül, R. (2001). İletişim ve etik. Ankara: Nobel Yayınları.

Bülbül, R. (2002). Basın ahlakı, basın özgürlüğ̈̈, basında özdenetim. İstanbul: Erdini Basım.

Büyükbaykal, G. (2004). Basın özgürlüğü kavramının anlamı ve önemi. İstanbul Üniversitesi İletişim Fakültesi Dergisi, 20(1), 43-47.

Çatalbaş, D. (2017). 1980 Sonrası Radyo ve Televizyon. K. Alemdar (Haz), Türkiye’de kitle iletişimi dün-bugünyarın cilt-I içinde (s. 485-520). Ankara: Gazeteciler Cemiyeti Yayınları.

Çavdar, T. (2013). Türkiye’nin demokrasi tarihi 1950’den günümüze. Ankara: İmge Yayınları.

Çeçen, A. (2000). İnsan hakları. İstanbul: Gündoğan Yayınları.

Duran, B. (2012). Türk parlamento tarihi-TBMM-XIX. dönem (1991-1995) I. cilt-yasama. Ankara: TBMM Basımevi. 
Duverger, M. (1986). Siyasal rejimler. T. Tunçdoğan (Çev.). Ankara: Sosyal Yayınlar (orijinal baskı tarihi 1986).

Gümüş, B. (2013). Siyasal Güçler. B. Dural (Haz.), Siyaset biliminde kuram-yöntem-güncel yaklaşımlar içinde (s. 173-228). Edirne: Paradigma Yayınları.

Hawks, B. B. (2002). Terör olaylarını basın özgürlüğüne etkileri: ABD ve Türkiye örneği. İstanbul: İstanbul Üniversitesi İletişim Fakültesi Yayınları.

Heywood, A. (1997). Demokrasi. Liberal Düşünce Dergisi, 8(1), 108-121.

Heywood, A. (2012). Siyaset. B. Özipek, B. Şahin, M. Yıldız, Z. Kopuzlu, B. Seçilmişoğlu, A. Yayla (Çev.). Ankara: Liberte Yayınları (orijinal baskı tarihi 1997).

İçel, K. ve Ünver, Y. (2009). Kitle haberleşme hukuku. İstanbul: Beta Yayınları.

Kapani, M. (2012). Politika bilimine giriş. Ankara: Bilgi Yayınevi.

Kara. A. M. (2004). Türk siyasal yaşamında 1961 sonrası bir olgu koalisyonlar. İstanbul: Otopsi Yayınları.

Kejanlığlu, B. (2004). Türkiye’de medyanın dönüşümü. Ankara: İmge Kitabevi.

Kışlalı, T. A. (1996). Siyaset bilimi. İstanbul: İmge Kitabevi.

Lewis, B. (2010). Demokrasinin Türkiye serüveni. İstanbul: Yapı Kredi Yayınları.

Manfred G. S. (2002). Demokrasi kuramlarına giriş. E. Köktaş (Çev.). Ankara: Vadi Yayınları (orijinal baskı tarihi 1995).

Neziroğlu, İ. ve Yılmaz, T. (2013). Hükümetler, programları ve genel kurul görüşmeleri cilt 8. (9 Kasım 1989-30 Ekim 1995). Ankara: TBMM Basımevi.

Neziroğlu, İ. ve Yılmaz, T. (2015). Koalisyon hükümetleri, koalisyon protokolleri, hükümet programları ve genel kurul görüşmeleri cilt 1. Ankara: TBMM Basımevi.

Özdemir, E. ve Atılgan, G. (2014). Siyasi Partiler. G. Atılgan ve E. A. Aytekin (Haz.), Siyaset bilimi, kavramlar, ideolojiler, disiplinler arası ilişkiler içinde (s. 239-251). İstanbul: Yordam Yayıncılık.

Özek, Ç. (1999). Basın özgürlüğünden bilgilenme hakkına. İstanbul: Alfa Yayınc1lık.

Özsever, A. (2004). Tekelci medyada örgütsüz gazeteci. Ankara: İmge Kitabevi.

Öztekin, A. (2013). Siyaset bilime giriş. Ankara: Siyasal Kitabevi.

Schumpeter, A. J. (2007). Kapitalizm, sosyalizm ve demokrasi. H. İlhan (Çev.). Ankara: Alter Yayınları (orijinal baskı tarihi 1942).

Şimşek, H. (2002). İnsan, siyaset ve demokrasi. İstanbul: İnsan ve Demokrasi Vakfı Yayınları.

Teziç, E. (1997). Anayasa hukuku. İstanbul: Beta Yayınları.

Tilıç, D. (2009). Utanıyorum ama gazeteciyim. İstanbul: İletişim Yayınları.

Tokgöz, O. (2015). Temel gazetecilik. Ankara: İmge Kitabevi.

Topuz, H. (2015). II. Mahmut'tan holdinglere Türk basın tarihi. İstanbul: Remzi Kitabevi.

Tunaya, Z. T. (1995). Türkiye’de siyasi partiler. İstanbul: Arba Yayınları.

Tutar, H. (2007). Türk siyasetinde sancılı yıllar. İstanbul: Bizim Kitaplar Yayınevi.

Ural, H. Ş. (1999). Demokrasi Kavramı, Toplumsal Değerler ve Birey. İlahiyat Fakültesi Dergisi, 40(1), 1-9.

Zürcher, J. E. (2011). Modernleşen Türkiye’nin tarihi. Y. Saner (Çev.). İstanbul: İletişim Yayınları (orijinal baskı tarihi 1993). 


\title{
Freedom of The Press in Coalition Governments: True Path Party and Social Democratic People's Party/Republican People's Party Case (1991-1996)
}

\author{
Göksel BASMACI $^{* *}$
}

In this study, under the direction of the DYP-SHP/CHP coalition government, legal regulations for the press and the general situation of the press were examined. In this sense, the aim of the study is to determine the way in which the freedom of the press and the laws enacted are shaped in this period. The study is important since it reflects the state of the press during the DYP-SHP/ CHP coalition period. In this study, the descriptive method was used and the relationship between democracy and press freedom was discussed in order to prepare the basis for the study.

Democracy is the rule of people by itself again (Heywood, 1997, p. 110). The fact that people have the right to accept or reject that people to rule is the triumph of democracy (Schumpeter, 2007, p. 373). The origin of word democracy stems from the unification of the Greek words of the people and the administration (Çeçen, 2000, p. 58). In the early ages, it was defined as the unstable sovereignty of the majority that formed society (Manfred, 2002, p. 28). Democracy guarantees individual rights and freedoms (Ural, 1999, pp. 2-3). In a democratic order, the press is important to protect the rights of individuals and to express themselves freely (Bülbül, 2001, p. 17). The freedom of the press is that news, ideas and findings can be handled within the framework of freedom and can be freely shared with mass media, such as newspapers, television, radio, cinema, internet, etc. (İçel and Ünver, 2009, p. 24). Thomas Jefferson, the third president of the United States, said: "I prefer a non-government press rather than a non-government government." and he showed the importance he gave to the press by saying this (Bülbül, 2002, pp. 88-89). Today, although the press is regarded as a fourth power, freedom of the press is not of equal importance (Büyükaykal, 2004, pp. 43-44). However, it is important for the individual to be informed in a neutral way in order to make the right choice when voting on the democratic grounds (Özek, 1999, p. 33).

** Research Assistant, İstanbul Arel Üniversitesi, İletişim Fakültesi, Gazetecilik, İstanbul, Türkiye, Orcid ID: 0000-00024640-9819 
Afterwards, party systems were discussed in this study. Political parties are organizations formed by people who have an organized continuity throughout the country and have adopted the same view (Şimşek, 2002, p. 32). Their struggle is to become the most basic target of the state power (Gümüş, 2013, p. 176). Party systems, which directly affect the shape of management, are formed within the political, cultural and economic structure of the country (Öztekin, 2013, p. 115). The fact that there is a single or multi-party system in one country constitutes the reflection of the values of the country (Kışlall, 1996, p. 238). Party systems is divided into a single, two and multiparty system (Kapani, 2012, p. 194). A single-party system is an organization that manages a country's policy with decisions taken by itself and does not allow other powers (Tunaya, 1995, p. 65). It is not possible to mention the competition conditions in this system (Özdemir and Atılgan, 2014, p. 246). In the two-party system, the state power is shared between the two parties, respectively (Heywood, 2012, p. 335). In order to establish a two-party system, it is decisive to agree on the main problems (Teziç, 1997, p. 334). In the multi-party system, the preferred coalition is that multiple parties come together to use the executive power in common (Tutar, 2007, p. 16). Since the government is formed by parties with different values, it is problematic to produce a clear government program (Duverger, 1986, p. 42).

Following these concepts, the study focused on the political activities of the government. In the elections on October 20,1991, the DYP took vote 27\% (Kejanlıoglu, 2004, p. 345). The most remarkable party was the RP (Zürcher, 2011, p. 421). The coalition, which determined democratization as a goal, aimed to achieve peace and development (Kara, 2004, p. 229). After Turgut Özal died on 17 April 1993, Suleyman Demirel became the president. Tansu Çiller was the first female prime minister of Turkey and was the head of the DYP (Lewis, 2010, p. 24). In this process, 35 of the writers who went to Sivas to participate in the Pir Sultan Abdal events on July 2, 1993 were burned to death as a result of the fire of the Madımak Hotel (Akşin, 2007, p. 293). During this period, the most fundamental problems were the terrorist incidents and the unrest in the country (Çavdar, 2013, pp. 314-320). On the other hand, in these years when banks were bankrupt, $95 \%$ of the interest rates had raised serious decreases in the stock market (Tutar, 2007, p. 322).

In the study, after transferring political events during the DYP-SHP/CHP government period, the focus of the study was on the government's legal practices towards the press and the general situation of the press. On November 25, 1991, the government said that freedom of the press would be ensured and this would be supported by the law (Neziroğlu and Yllmaz, 2013, pp. 6570-6592). In this period, the privatized state monopoly of radio and television was terminated (Çatalbaş, 2017, p. 495). A special television called Magic Box started broadcasting, but later published a circular for the closure of illegal radios and televisions (Asker, 2017a, p. 644). In this context, special publications were closed since they were unconstitutional (Duran, 2012, p. 27). The government, which was reestablished on July 5, 1993, received the vote of confidence (Topuz, 2015, p. 297). The government then made new promises to ensure freedom of the press (Neziroğlu and Yilmaz, 2015, pp. 10801822). On 8 July, 1993, 133th article of the constitution was revised and the monopoly on radio and television was abolished (Asker, 2017a, p. 649). Within the scope of the law which came into force on April 16, 1994, the RTUK started to come into office (Tokgöz, 2015, p. 51). With this system, an audit was established on radios and televisions (Birol, 2018, p. 66). The law number 212, which provides 
various guarantees to journalists, also lost its importance (Özsever, 2004, p. 111). Unrest prevailed across the country and there were unknown acts of perpetrators (Kejanlığlu, 2004, p. 349). Although there was a decrease in the murder cases in 1994, the pressures continued. $41 \%$ of the cases in the Istanbul State Security Courts were opened for the press (Tilıç, 2009, p. 295). At the meeting held by the International Press Institute, 1260 publications were confiscated in Turkey between January and February 1995 and 103 journalists and writers were in prison at the end of February (Topuz, 2015, pp. 304-305). Before the elections in 1995, the $8^{\text {th }}$ article of the anti-terror law was amended and the pressures were reduced (Asker, 2017b, p. 680). The government's efforts to enter the European Union were effective in making these decisions (Hawks, 2002, p. 48). As a result, the government, which had promised freedom of the press, democracy, equality and human rights during the formation process, failed to provide these elements and displayed an authoritarian management in the press field. Within the framework of these discussions, it was concluded that the DYP-SHP/CHP coalition failed to provide freedom of the press and with the laws it enacted, negatively affected the press and the press workers. 